\title{
Creative Graduate Pathways Within and Beyond the Creative Industries
}

\author{
Ruth Bridgstock, Ben Goldsmith, Jess Rodgers and Greg Hearn
}

Scholarly discussions of the creative workforce invariably take one of two seemingly incompatible positions. First, cultural studies scholars have spent considerable time describing the ongoing employment insecurity of those involved in creative work, and the antecedents and effects of this employment 'precarity'. In striking contrast to this position is a significant body of policy and large scale empirical work that demonstrates the importance of creative work and workers to the innovation economy and economic growth. These two positions are typically presented as incompatible with one another, and remarkably few attempts have been made to achieve any kind of rapprochement between the two. However, recent investigations propose that the creative workforce is much more heterogeneous than either of these positions suggest: that creative workers are found throughout the economy and not just within the creative and cultural sectors; that certain creative activities, industry segments and sectors are associated with greater precarity and/or greater economic growth than others; that, therefore, creative careers are far more complex and diverse than previously thought; and following on from all of this, that the task of creative educators is much more challenging than previously supposed.

This special issue explores the nuances of creative work, the kinds of value that creative workers add through work of various types, creative career identities, and the implications for educators who are tasked with developing a capable creative workforce. In this introductory article, we commence by providing a brief overview of the creative labour debates, and the evidence for each position. We present the latest literature in this area that starts to speak to how diverse and complex the landscape of creative work actually is. We then introduce each of the articles in the special issue and indicate how they contribute to a more multi-faceted picture of creative activity.

\section{Precarious creative work}

Creative careers have traditionally been described as 'precarious' - that is, involving chronic unemployment and underemployment. Characterisations of 'portfolio careers' comprising piecemeal creative and non-creative jobs, shortterm project-based and self-employment-based work abound (e.g., Bridgstock 2005, Ross 2009, Throsby and Zednik 2010). Some theorists (e.g., Hall 1996, Howkins 2001) have touted lifestyle benefits of the varied, entrepreneurial aspects of the portfolio career, including flexibility, autonomy and excitement. Recently, Morgan et al (2013) suggested that many young creative workers have started to internalise these values, finding portfolio work both liberating and adaptive - a phenomenon Neff (2012) terms 'venture labour'.

However, a significant number of studies indicate that creative workers are often driven to portfolio working arrangements through financial necessity or industry norms and configurations (in the creative industries, much work is project-based and, therefore, of finite length). In portfolio work, the worker 
assumes individual risk and responsibility for all aspects of career, including those due to economic fluctuations, market and supply chain vagaries, and personal misfortune (Gregg 2011, Neff 2012).

Cultural economists such as Menger (1999) indicate that an oversupply of creative workers is part of what underlies the precarity phenomenon.

According to this school of thought, creative workers derive 'psychic income' from creative work and are, therefore, likely to remain in the industry despite inadequate financial income, underemployment and other adversity. The possibility of a lucky break leading to exceptional success can also be a significant factor (Taylor and Littleton 2008). Rather than going in search of better employment prospects in other industries, creative workers will often remain and 'self-exploit', by working free or at reduced rates (Hesmondhalgh and Baker 2010).

Precarity and self-exploitation both appear to be very common among graduates of creative degrees as they move into the world of work. Creative graduates can struggle through an extended education to work transition involving episodes of unpaid work experience and internships, additional education or / training, and reliance on family, social security and/or 'day jobs' for financial support (Galloway et al. 2002). Studies of graduate transitions indicate that many students also experience a significant period of personal and professional identity uncertainty (Buckham 1998, Nystrom 2009). Further, the social network-based informal processes involved in finding or creating creative work can be a significant barrier to entry (McRobbie 2002). Some scholars have argued that these 'who you know' job acquisition and creation processes are a mechanism for exclusion and discrimination (Lee 2011).

\section{The creative economy}

Over the last fifteen years, a body of literature in striking contrast to the 'precarious labour' literature has arisen. This 'creative economy' corpus argues that creative work and creative workers are of vital importance to economic growth in post-industrial economies, via the addition of creative and cultural value to national innovation systems (Hearn and Bridgstock 2010, Cunningham 2014b). This work draws upon earlier commentary around the 'culturalisation' of industry (Lash and Urry 1994). Creative economy theorists argue that creative and cultural knowledge and skills, along with digital capability, drive innovation throughout the economy, reaching beyond the creative industries (Potts and Cunningham 2008, Hearn et al. 2014). According to Bakhshi et al $(2012,45)$, 'the creative industries bring together a particular combination of [creative] content and ICT skills; their integrity as an emerging economic entity relies on this combination'. These theorists argue demand for creative workers is in fact increasing and that these workers enjoy conditions comparable to the rest of the workforce (e.g., Cunningham, 2014a).

In making these claims, creative economy scholars have relied on evidence from large scale statistical industry mapping studies, beginning with the Creative Industries Mapping Study by the UK Department for Culture, Media and Sport (DCMS) (Department for Culture, Media and Sport 1998) and continuing using various methodologies and in various countries. These 
scholars consistently report higher-than-average growth of the size of the creative industries as an industry sector and in the size of the creative workforce. The next section of this article presents an overview of one dominant creative workforce mapping methodology: the Creative Trident.

\section{The Creative Trident: Within and Beyond the Creative Industries}

Over the last decade, the Australian Research Council Centre of Excellence in Creative Industries and Innovation $(\mathrm{CCl}$ ) has been engaged in measuring the creative workforce using a methodology that relies on Census data (see Cunningham 2014a for a description of the development). The 'Creative Trident' was thus developed out of an observation that the size and significance of the Creative Industries cannot be measured accurately by examining industry activity in isolation. $\mathrm{CCl}$ researchers suggest that previous mapping studies have underestimated the creative workforce by up to $40 \%$ (Cunningham 2014a).

The Creative Trident model incorporates: (1) the total of creative occupations within the core creative industries (specialists); (2) the creative occupations employed in other industries (embedded); and (3) the business and support occupations employed in creative industries, which are often responsible for managing, accounting for and technically supporting creative activity (support). According to the Trident model, the number of people employed in the 'creative economy' is the total of creative industries employment plus embedded employment. In this model, Creative Industries industries and occupations comprise: Architecture, Design and Visual Arts; Music and the Performing Arts; Film, Radio and Television; Writing and Publishing; Advertising and Marketing, and Software and Digital Content.

Table 1. The Creative Trident

\begin{tabular}{|l|l|l|l|}
\hline & $\begin{array}{l}\text { Employment in } \\
\text { creative industries }\end{array}$ & $\begin{array}{l}\text { Employment in other } \\
\text { industries }\end{array}$ & Total \\
\hline $\begin{array}{l}\text { Employment in } \\
\text { creative occupations }\end{array}$ & Specialist creatives & Embedded creatives & $\begin{array}{l}\text { Total employment in } \\
\text { creative occupations }\end{array}$ \\
\hline $\begin{array}{l}\text { Employment in other } \\
\text { occupations }\end{array}$ & Support workers & & \\
\hline Total & $\begin{array}{l}\text { Total employment in } \\
\text { creative industries }\end{array}$ & & $\begin{array}{l}\text { Total creative } \\
\text { workforce }\end{array}$ \\
\hline
\end{tabular}

Creative Trident mapping reveals that in a number of economies the creative workforce is growing at a faster rate than the general economy, and that on average the creative workforce earns salaries above national averages. The Trident has also demonstrated that more creative workers are employed in other sectors (embedded) than are found as specialists inside the creative industries sectors, thus providing support for the notion that creative activity is important throughout the economy (Cunningham 2014b). Further, embedded creative workers seem to experience precarious labour conditions to a lesser extent than specialists. When Potts and Shehadeh (2014) analysed the large 
scale longitudinal survey of Australian Household, Income and Labour Dynamics, they found that embedded creative workers were just as likely as Australian workers in general, to be employed in secure, full-time jobs.

\section{Creative Trident mark II}

In 2012, the Creative Trident methodology was further refined to identify two creative activity groups: Cultural Production, comprising the sectors and occupations concerned with the production of cultural artefacts and experiences for final consumption (B2C), including Film, Television and Radio, Publishing, Music, Performing Arts and Visual Arts; and Creative Services, comprising the sectors and occupations primarily concerned with business-tobusiness (B2B) activities like Design, Architecture, Software and Digital Content, Advertising and Marketing (Cunningham 2014a). This categorisation of creative activity allowed for acknowledgement and exploration of the diversity of economic contribution made by different areas of the creative workforce. Through Creative Trident mark II, it was observed that the majority of above-average growth in the creative workforce was generated within Creative Services, either in Creative Service industries (support and specialists) or Creative Service occupations embedded in other industries (embedded in Cultural Production industries as well as non-Creative Industries). The Creative Trident Mark II outcomes for Australia 2006-2011 are shown in table 2.

Table 2. Creative Economy Employment Growth Rates by Trident Mark II Categories based on 2006 and 2011 Australian Census data

\begin{tabular}{|l|c|c|c|}
\hline & $\begin{array}{c}\text { Cultural Production } \\
\text { Sectors }\end{array}$ & $\begin{array}{c}\text { Creative Services } \\
\text { Sectors }\end{array}$ & Other Sectors \\
\hline $\begin{array}{l}\text { Cultural Production } \\
\text { Occupations }\end{array}$ & $2.60 \%$ & $3.50 \%$ & $-0.80 \%$ \\
\hline $\begin{array}{l}\text { Creative Services } \\
\text { Occupations }\end{array}$ & $1.70 \%$ & $4.80 \%$ & $2.50 \%$ \\
\hline Support Occupations & $-0.20 \%$ & $4.30 \%$ & \\
\hline & Creative Economy 2.8\% & & \\
\hline & rest of economy 2.0\% & & \\
\hline
\end{tabular}

Table 2 shows that between 2006 and 2011, Australia's Creative Economy as a whole grew faster than the economy as a whole (2.8\% as opposed to $2.0 \%)$, and that the majority of growth is found in Creative Services industries, with large Creative Services industry growth in Cultural Production jobs, Creative Services jobs, support jobs, and also growth in Creative Services jobs embedded in other sectors. For Cultural Production industries, growth rates above the economy only occurred for Cultural Production jobs in the core Cultural Production industries, with negative growth rates recorded for support occupations in Cultural Production and also Cultural Production embedded roles. 
Relatively high growth patterns in Creative Services and Creative Service occupations embedded in other industries would seem to be in line with the progressive embedding of digital applications and services into the general economy, including online and digital communication, design, advertising, and software/apps development (see also Cunningham 2014b and Goldsmith 2014 for further discussion of this). Within the digital economy, there is large and growing core demand for converged digital technologies of production, reproduction and dissemination, such as digital and social tools and media, and a growing general digital, design and communications skill base and consciousness. On the other hand, Cultural Production is typified by the 'A list/B list', 'nobody knows' and 'arts for arts sake' dicta proposed by Caves (2000), with demand subject to fluctuation and tied to the availability of discretionary income.

Under Trident Mark II analysis, Cultural Production creative workers and segments are argued to be more likely to be associated with precarious employment. Self employment statistics can be taken as an indication of this. The 2011 Australian Census analyses reveal that self-employment is far more likely, at $13 \%$, among workers within the Creative Industries, than the workforce overall, at 6\%. Within the Creative Industries workforce, selfemployment is very likely among those in Cultural Production: more than half (56\%) of employment in the industry classification for Creative Artists, Musicians, Writers and Performers was self-employment.

\section{The need to go deeper than the census}

While the high level, census-based studies of the creative workforce are valuable in terms of describing the extent and economic contribution of creative activity, they are also limited, particularly in terms of fine grained investigations into the experiences and behaviour of creative individuals and groups. It is not possible to investigate career trajectories, configurations of current employment (such as the portfolio career), or the relationship of education and qualification to career. For instance, census data is not able to give insights relating to the career development of creative practitioners over the lifespan; the development of career identity and the idea of managing career risk at certain times of life by moving outside the Creative Industries, or moving from the creative arts into other areas of the Creative Industries (Oakley et al. 2008). Nor can it address the idea that creatives can manage precarity by balancing between a range of labour conditions as part of the portfolio career - for example, by engaging in arts practice on a self-employed basis at the same time as holding down creative services work or even a 'day job'.

Census data collections tend to ask only about the respondent's primary job, thus ignoring portfolio career arrangements entirely; they also categorise by occupational and industry codes that are often outdated in the context of the digital economy, too granular, or too broad for the scope of enquiry (see Goldsmith, 2014). These large scale studies can also make overly neat distinctions between employment types, and underreport on creative work that is undertaken as a second or third job, and/or undertaken as part of selfemployment. 


\section{Creative Graduate Career Studies}

Various kinds of survey work looking at creative graduate trajectories and outcomes has added some important depth and texture to what is known about creative launch experiences and the early creative career. The 'Creative Graduates, Creative Futures' study in the United Kingdom (Ball et al. 2010) involved 3,500 art, media, crafts and design graduates up to eight year years after course completion, following the seminal Destinations and Reflections study (Blackwell and Harvey 1999). Ball et al found that $78 \%$ of the participants in the study were engaged in creative work of some sort, although creative work was defined very flexibly, including a much broader range of so-called creative occupations than generally accepted (including how creative occupations are defined in the Trident method). This study also found precarious employment among the graduates studied, especially in the first year after graduation, with high levels of self-employment (45\% of the participants surveyed) and portfolio working ( $48 \%$ had more than one job). graduation.

Second, creative graduate destinations in the United Kingdom have also been explored through analysis of the UK-wide 'Destinations of Leavers from Higher Education' (DLHE) survey matched with student record data, collected as part of the 'Students in Higher Education' survey. Comunian and colleagues (Comunian et al. 2010, Comunian et al. 2011) analysed surveys submitted by graduates from Advertising, Architecture, Crafts, Design, Film and Television, Fine Art, Music, Performing Arts, Technology and Writing and Publishing disciplines. They found a complex picture of destinations that nonetheless broadly supported the findings of Trident Mark II in Australia: that some creative graduates (particularly those from largely Creative Servicesrelated degrees, such as architecture, advertising and publishing) were much more likely to be employed full-time and with higher wages than others (particularly those from broadly Cultural Production-related degrees, such as craft, and the fine and performing arts).

In Australia, Bridgstock (2011; Bridgstock \& Cunningham, 2014) conducted a series of 'bottom-up' studies of creative graduate outcomes. Bridgstock (2011) tracked graduates of Creative Industries undergraduate degree programs for one year after course completion. While the focus of this study was to identify capability and attitudinal predictors of career success in the creative career, Bridgstock also found a significant disciplinary difference in earnings-based career success measures, with design and digital graduates earning significantly more overall and from creative work than graduates of visual and performing arts programs. However, the graduates of visual and performing arts programs maintained high ratings on subjective (self-defined) career success, reflective of Hesmondhalgh and others' (Banks and Hesmondhalgh 2009) suggestions around 'good work' and important noneconomic value associated with creative work.

Cunningham and Bridgstock (2012; Bridgstock \& Cunningham, 2014) conducted a single-institution study of 400 journalism, media and communications graduates going back to 10 years post-course completion. The data in that study supported Creative Trident findings that journalism, media and communications professionals are found throughout the economy. 
Overall, the graduates in this study enjoyed high levels of employment and gave positive accounts of the relevance of their courses to working life, with minimal precarious employment. In general, courses were regarded as successful in delivering the generic capabilities, skills and orientations that facilitated graduate employability, irrespective of eventual employment type. This finding was congruent with previous data suggesting that creative graduates are fairly well equipped in terms of core disciplinary and broad generic employability skills (such as written communication, critical thinking and numeracy) (Haukka et al. 2010), although they may experience skills gaps in specific multiplatform and digital content, intellectual property and commercial areas (Galloway et al. 2002, Haukka 2011).

\section{Higher education and preparation for creative work}

To date, the creative labour debate has not placed much emphasis on its implications for higher education degree programs. The transition from education to work and career for creative graduates can be enormously challenging for many, as discussed above. Matthews (2011) suggests that the process of moving from creative education to work is more like 'translation' than transition, with graduates engaging in a process of recontextualisation and reinterpretation of knowledge, capabilities and practices acquired during degree courses. Further, the transition can involve substantial professional and personal identity revision.

Higher education can do more than it does presently to smooth graduates' transitions into the workforce. Building into creative programs critical engagement with creative workforce issues, knowledge of a wider range of career destinations, and higher-level management and self-management capabilities will helping to sustain many graduates when faced with the many challenges in building creative careers (see also Bridgstock \& Carr, 2013).

\section{Why this special issue?}

This special issue examines pathways from creative education to work, and preparation for these pathways within higher education programs, in the light of the creative labour debates outlined above. In this special issue, we are concerned with the creative launch experiences, destinations and contributions of graduates emerging into an enormously diverse and heterogeneous creative workforce, coming from university degree programs that tend to be focussed on the development of specialist creative disciplinary skills and fairly narrow career identities (Bridgstock, 2013; Bridgstock \& Cunningham, in press). The articles in this special issue range from quantitative analyses of large longitudinal data sets to in-depth qualitative cases. Its contribution is to provide a range of studies that speak to the complexity found in the work life of creative careers.

In the first article, Digital technology and creative arts career patterns in the UK creative economy, Roberta Comunian and colleagues revisit their DLHE survey data-based analytical methodology (see also Comunian et al, 2010 \& 2011) to explore the roles that digital and creative arts capability play in the creative economy, by examining employment patterns and destinations of digital technology (DT) and Creative Arts and Design (CAD) graduates in the United Kingdom. Following on from propositions out of Trident Mark II, the 
article explores how digital and creative graduates (and their skills) are embedded across industries beyond the creative industries, and how they are concentrated within creative sub-sectors. The authors also look at patterns of employment and unemployment, and the levels of financial reward associated with creative and digital graduate careers, thus teasing out issues of skill and economic value.

In "Embedded creative workers and creative work in education", Goldsmith and Bridgstock undertake a systematic empirical examination of the connection between creative work and workers, and education work and industries. Taking as their point of departure that education tends to be the most common industry sector into which creative workers are 'embedded' outside the creative industries, they surveyed 900 graduates from creative undergraduate degrees in Australia to examine the prevalence and characteristics of education and education-related employment among creative graduates. Goldsmith and Bridgstock found a very wide range of motivations and drivers for creative graduates engaging in education work, but perhaps most interestingly found that for many of the study participants, education work is often imbued with creativity, and that this creative activity is linked strongly with career satisfaction no matter what the job title.

The third article, "Creative work careers: pathways and portfolios for the creative economy", is concerned with the complex pathways into, within / outside and out of creative work. Daniel Ashton examines the balance of creative and non-creative work in the creative career; challenges to obtaining creative employment; and career exit strategies used by creative workers. He then looks at students from creative courses that go into non-creative occupations in other industries, to highlight the challenge students face around industry expectations and competition with other graduates in the transition from higher education to employment. Ashton's article engages critically and problematises the Trident model of the creative workforce in the light of the temporary and contingent nature of creative employment.

The "Careers of fine artists and the embedded creative" is a rich qualitative exploration of the careers of a cohort of graduates from Fine Arts degrees in the decade since graduation. Charlotte Carey writes about strong fine art career expectations reinforced by art school pedagogy, and the artist career identities that continued among the participants, along with a continuing 'compulsion to create'. Career choices and trajectories among the group for the most part enabled participants to continue their arts practices, or to satisfy their creativity in other ways. In their 'non-creative' work, for instance, participants' creative expertise often manifested in terms of facilitation of others' creativity. While the careers of participants were complex, entrepreneurship continued to feature in terms of continued forays into selfemployment, although Carey notes that creative entrepreneurship education was lacking in their initial degree experiences.

In the final article "The rise of the embedded designer in the creative industries", Katja Fleischmann and Ryan Daniel present a mixed-methods study of visual design student / graduate career aspirations and expectations, and examine the roles of graduate visual designers currently working in 
embedded jobs. Their study reveals very low awareness and knowledge among students, and perhaps also tertiary educators, of non-specialist design job roles, and points to the need for explicit inclusion of curricula aimed at embedded career and other related options (such as digital marketing) for graduates. This article emphasises the changing composition of creative work, with increased bundling of creative and digital services within creative roles within and outside the creative industries.

References

Bakhshi, H., Freeman, A. \& Higgs, P., 2012. A dynamic mapping of the UK's creative industries. London: NESTA.

Ball, L., Pollard, E. \& Stanley, N., 2010. Creative graduates, creative futures. London: Council for Higher Education in Art and Design.

Banks, M. \& Hesmondhalgh, D., 2009. Looking for work in creative industries policy. International Journal of Cultural Policy, 15 (4), 415-430.

Blackwell, A. \& Harvey, L.,1999. Destinations and reflections: Careers of British art, craft and design graduates. Birmingham: CRQ.

Bridgstock, R., 2005. Australian artists, starving and well-nourished: What can we learn from the prototypical protean career? Australian Journal of Career Development, 14 (3), 40-48.

Bridgstock, R., 2011. Skills for creative industries graduate success. Education \& Training, Vol. 53 (1), 9-26.

Bridgstock, R., 2013. Not a dirty word: Arts entrepreneurship and higher education. Arts and Humanities in Higher Education, 12 (2-3), 122-137.

Bridgstock, R. \& Carr, L., 2013. Creative entrepreneurship education for graduate employability in the creative arts. In: Holmes, J. ed. The CALTN Papers: The Refereed Proceedings of the Creative Arts Learning and Teaching Network Symposium 2013. Hobart: Tasmanian College of the Arts, University of Tasmania and the Creative Arts Learning and Teaching Network, 8-35.

Bridgstock, R. \& Cunningham, S., 2014. Graduate careers in journalism, media and communications within and outside the sector: Early career outcomes, trajectories and capabilities. In: Hearn, G., Bridgstock, R., Goldsmith, B. \& Rodgers, J. eds. Creative work beyond the creative industries: Innovation, employment and education. London: Edward Elgar.

Buckham, L., 1998. "Perhaps we're thinking there isn't a career out there for us": A study of undergraduates' attitudes to their future prospects. British Journal of Guidance and Counselling, 26 (3), 417-33.

Caves, R.E. (2000). Creative industries: Contracts between art and commerce. Cambridge: Harvard University Press. 
Comunian, R., Faggian, A. \& Jewell, S., 2011. Winning and losing in the creative industries: An analysis of creative graduates' career opportunities across creative disciplines. Cultural Trends, 20 (3-4), 291-308.

Comunian, R., Faggian, A. \& Li, Q.C., 2010. Unrewarded careers in the creative class: The strange case of bohemian graduates. Papers in Regional Science, 89 (2), 389-410.

Cunningham, S., 2014a. Creative labour and its discontents: A reappraisal. In: Hearn, G., Bridgstock, R., Goldsmth, B. \& Rodgers, J. eds. Creative work beyond the creative industries: Innovation, employment and education. London: Edward Elgar.

Cunningham, S., 2014b. Hidden innovation: Policy, industry and the creative sector. Lanham, MD: Lexington Books / Rowman \& Littlefield.

Cunningham, S. \& Bridgstock, R., 2012. Say goodbye to the fries: Graduate careers in media, cultural and communication studies. Media International Australia: Incorporating Culture and Policy, 145, 145-160.

Department for Culture Media and Sport,1998. Creative industries mapping document 1998. London: DCMS.

Galloway, S., Lindley, R., Davies, R. \& Scheibl, F., 2002. A balancing act: Artists' labour markets and the tax and benefit systems. London: Arts Council of England.

Goldsmith, Ben (2014) Embedded digital creatives. In Hearn, Gregory N., Bridgstock, Ruth S., Goldsmith, Ben, \& Rodgers, Jess (Eds.) Creative Work Beyond the Creative Industries: Innovation, Employment and Education. Edward Elgar Publishing, London.

Gregg, M., 2011. Work's intimacy. Cambridge: Polity.

Hall, D., 1996. The career is dead - long live the career: A relational approach to careers. San Francisco: Jossey-Bass.

Haukka, S., 2011. Education-to-work transitions of aspiring creatives. Cultural Trends, 20 (1), 41-64.

Haukka, S., Hearn, G.N., Brow, J. \& Cunningham, S.D., 2010. From education to work in Australia's creative digital industries: Comparing the opinions and practices of employers and aspiring creatives. Brisbane: ARC Centre of Excellence in Creative Industries and Innovation.

Hearn, G., Bridgstock, R., Goldsmith, B. \& Rodgers, J. eds. 2014. Creative work beyond the creative industries: Innovation, employment and education. London: Edward Elgar.

Hearn, G. \& Bridgstock, R.S., 2010. Education for the creative economy: Innovation, transdisciplinarity and networks. In: Peters, M. \& Araya, D. eds. Education in the creative economy. New York: Peter Lang. 
Hesmondhalgh, D. \& Baker, S., 2010. A very complicated version of freedom: Conditions and experiences of creative labour in three cultural industries. Poetics, 38 (1), 4-20.

Howkins, J., 2001. The creative economy: How people make money from ideas. London: Penguin.

Lash, S. \& Urry, J., 1994. Economies of signs and space. London: Sage.

Lee, D., 2011. Networks, cultural capital and creative labour in the British independent television industry. Media, Culture \& Society, 33 (4), 549565.

Matthews, N., 2011. Transition or translation?: Thinking through media and cultural studies students' experiences after graduation. Cultural Studies Review, 17 (2), 28-48.

McRobbie, A., 2002. Clubs to companies: Notes on the decline of political culture in speeded up creative worlds. Cultural Studies, 16 (4), 516-531.

Menger, P.M., 1999. Artistic labour markets and careers. Annual Review of Sociology, 25, 541-574.

Morgan, G., Wood, J. \& Nelligan, P., 2013. Beyond the vocational fragments: Creative work, precarious labour and the idea of 'flexploitation'. The Economic and Labour Relations Review, 24 (3), 397-415.

Neff, G., 2012. Venture labor: Work and the burden of risk in innovative industries. Massachusetts: MIT Press.

Nystrom, S., 2009. The dynamics of professional identity formation: Graduates' transitions from higher education to working life. Vocations and Learning, 2 (1), 1-18.

Oakley, K., Sperry, B. \& Pratt, A., 2008. The art of innovation: How fine arts graduates contribute to innovation. London: NESTA.

Potts, J. \& Cunningham, S., 2008. Four models of the creative industries. International Journal of Cultural Policy, 14 (3), 233-247.

Potts, J. \& Shehadeh, T., 2014. Compensating differentials in creative industries and occupations: Some evidence from HILDA. In: Hearn, G., Bridgstock, R., Goldsmith, B. \& Rodgers, J. eds. Creative work beyond the creative industries: Innovation, employment and education. London: Edward Elgar.

Ross, A., 2009. Nice work if you can get it: Life and labor in precarious times. New York: NYU Press.

Taylor, S. \& Littleton, K., 2008. Art work or money: Conflicts in the construction of a creative identity. The Sociological Review, 56 (2), 275-292. 
Throsby, D. \& Zednik, A.,2010. Do you really expect to get paid? An economic study of professional artists in Australia. Melbourne: Australia Council for the Arts. 